\title{
WHOLE GENOME SEQUENCING AND THE COMPARATIVE ANALYSIS OF HOUSEKEEPING LOCUSES AND VIRULENCE GENES FROM THE COMMERCIAL STRAINS OF Bacillus thuringiensis WITH INSECTICIDAL ACTIVITY
}

\section{V.I. SAFRONOVA, A.L. SAZANOVA, I.G. KUZNETSOVA, Zh.P. POPOVA, S.D. GRISHECHKINA, V.P. ERMOLOVA, E.E. ANDRONOV}

All-Russian Research Institute for Agricultural Microbiology, Federal Agency of Scientific Organizations, 3, sh. Podbel'skogo, St. Petersburg, 196608 Russia, e-mail v.safronova@rambler.ru Acknowledgements:

Supported by the Ministry of Education and Sciences of the Russian Federation (Agreement № 14.604.21.0024, RFMEFI60414X0024)

Received March 30, 2015

\section{Abstract}

Russian collection of agricultural microorganisms (RCAM) supports 37 strains of $\mathrm{Ba}$ cillus thuringiensis with pronounced insecticidal activities, which are used for the production of phytoprotective biopreparations. The effectiveness of biopreparations depends on the quality of the microbial material. Monitoring of the purity and authenticity of the commercial strains can be accomplished by their molecular-genetic certification. Currently, the most effective technology for detailed genetic characterization of strains is a whole genome sequencing. However, despite the obvious demand for whole genome sequencing for the certification of commercial strains, its widespread use is limited because of considerable labour-intensive and cost. Therefore, the developing of rapid methods for high-throughput sequencing is necessary to reduce the cost of analysis and the terms of its implementation. One possible solution might be to analyze the part of genome, which includes the most taxonomically and functionally important genetic loci (referent-complexes). The goal of this work was to detect the referent-complexes of $10 \mathrm{~B}$. thuringiensis strains having different serotypes. After receiving whole genome sequences the comparative analysis was carried out to search for the most divergent genetic loci that determine the uniqueness of strains. To identify most divergent loci of housekeeping genes and virulence genes in the strains, we used BioNumerics («Applied Maths», USA) program and MEGA v. 5.0 program for clustering according to Neighbour-Joining method. As a result, 10 housekeeping genes ( $g l p T, g l p F$, pyrE, purF, purH, pta, gyrB, fts $A$, panC and isd), as well as 8 virulence genes ( $h b l A, h b l C, h b l D$, nhe $A$, nhe $C$, capA, capC and inA) were selected. For each strain two referent complexes were constructed, representing the concatenated sequences of selected housekeeping and virulence loci taken separately. Total length of the referentcomplexes was 11809 and $10094 \mathrm{bp}$ respectively. In the future the sets of primers will be created for multiplex analysis of referent complexes in the high-throughput DNA sequencing and the rapid method for genetic certification of the commercial B. thuringiensis strains will be developed.

Keywords: Bacillus thuringiensis, whole genome DNA sequencing, housekeeping and virulence genes, genetic certification.

Microorganism strains with a pronounced (target) practical value are the basis for any microbial technology. Cultivation of strains during their laboratory storage and manufacturing process is often accompanied by the loss of their target properties and contamination (pollution) up to the full replacement by contaminants. As a result, microbial material of poor quality can be used which causes the reduction of production efficiency and the risk of the use of pathogenic microorganisms. Monitoring of the purity and authenticity of commercial strains can be accomplished by their molecular genetic certification. For this purpose, the latest molecular genetic methods such as the amplified DNA fragment length polymorphism analysis (AFLP fingerprinting) [1], pulse-electro- 
phoresis method [2, 3], and high-performance whole genome sequencing [4-8] are used currently. These techniques make it possible to identify the unique characteristics of microorganism cultures that can be used to create strain specific passports. Currently, the whole genome sequencing is considered the most effective technology for detailed genetic characterization of microorganism strains. However, despite the obvious demand for whole genome sequencing for the certification of commercial strains, its widespread use is limited because of considerable labor intensive and cost. Therefore, the developing of rapid methods for high-throughput sequencing is necessary to reduce the cost of analysis and the terms of its implementation. One possible solution might be to analyze not the whole genome but the most taxonomically and functionally important genetic loci (so called referent complexes).

The All-Russian Research Institute of Agricultural Microbiology (ARRIAM) departmental collection of beneficial agricultural microorganisms (RCAM) supports 37 strains of Bacillus thuringiensis with pronounced insecticidal activities used for the production of phytoprotective biopreparations (bitoxibacillin, bactoculicid, batsikol).

The goal of this study was to detect the whole genome sequencing of 10 Bacillus thuringiensis strains having different serotypes, to perform their comparative analysis and to search for the most divergent genetic loci to further develop a rapid method of reliable authentication of these species commercial strains.

Technique. Bacillus thuringiensis var. thuringiensis, B. thuringiensis subsp. darmstadiensis and B. thuringiensis var. israelensis strains were cultured on meat-peptone agar (MPA) at $28{ }^{\circ} \mathrm{C}$ [9]. The strains are placed at Station of Low Temperature Automated Storage of Biological Samples of RCAM [10]. Information about the strains is available online in the RCAM database at ARRIAM web-site (http://www.arriam.spb.ru).

To isolate bacterial DNA, $3 \mathrm{ml}$ of overnight culture of strains in meatpeptone broth (MPB) were taken [9], then the cells were pelleted by centrifugation at 13,400 rev/min for $2 \mathrm{~min}$. The pellet was washed with $1 \mathrm{ml}$ of buffer 1 (25 mM TrisHCl $\mathrm{pH}=8.0 ; 10 \mathrm{mM}$ EDTA) and centrifuged again. The pellet was re-suspended in $100 \mu \mathrm{l}$ of lysing mixture containing $960 \mu \mathrm{l}$ of buffer $1,3 \mathrm{mg}$ of lysozyme, and $25 \mu \mathrm{l}$ of RNase $(10 \mathrm{mg} / \mathrm{ml})$ and incubated for $20 \mathrm{~min}$ at $37{ }^{\circ} \mathrm{C}$. Then, $500 \mu \mathrm{l}$ of proteinase $\mathrm{K}$ in buffer $2(10 \mathrm{mM}$ TrisHCl $\mathrm{pH}=8.0 ; 5 \mathrm{mM}$ EDTA; $0.5 \%$ SDS) was added to the mixture and the latter was incubated for 30 minutes at $55{ }^{\circ} \mathrm{C}$. After that, $60 \mu \mathrm{l}$ of $3 \mathrm{M}$ sodium acetate and $750 \mu \mathrm{l}$ of phenol:chloroform mixture (1:1) was added, vortexed for $5 \mathrm{~min}$ and centrifuged at $14,000 \mathrm{rev} / \mathrm{min}$ for 10 minutes. Supernatant was transferred into clean tubes, and $750 \mathrm{ml}$ of phenol:chloroform (24:1) mixture was added, vortexed for $5 \mathrm{~min}$ and centrifuged again. Supernatant was transferred into clean tubes, an equal volume of isopropyl alcohol was added, the mixture was gently stirred for $5 \mathrm{~min}$ and centrifuged at $13,400 \mathrm{rev} / \mathrm{min}$ for 10 minutes. Supernatant was separated, the pellet was washed with $70 \%$ ethanol and dried. $\mathrm{H}_{2} \mathrm{O}$ MQ $(50 \mu \mathrm{l})$ was added to the residue, stirred and heated at $65{ }^{\circ} \mathrm{C}$ for $5 \mathrm{~min}$. Additional cleaning of the isolated DNA was performed using the AxyPrep Multisource Genomic DNA miniprep Kit (Axygen, USA) according to the manufacturer's recommendations.

Concentration and purity of DNA was assessed using the SpectroStar Nano spectrophotometer (BMG Labtech GMbH, Germany) at four wavelengths of 230, 260, 280 and $340 \mathrm{~nm}$. The nucleotide sequence of genomic DNA was determined using the Junior GS pyrosequencer (Roche Applied 
Science, Germany) according to manufacturer's recommendations. The work on assembling reeds was performed using the CLC Genomics Workbench 7.5.1 program (CLC bio QIAGEN, Germany, http://www.clcbio.com/products/clc-genomics-workbench/).

To identify the most divergent loci of housekeeping and virulence genes in B. thuringiensis strains, we used the BioNumerics (Applied Maths, USA) program. To create dendrograms reflecting the phylogenetic relationship between the studied strains, the clusters of selected housekeeping gene sequences and separate virulence genes were processed using the MEGA v. 5.0 (NeighbourJoining method).

Results. Commercially valuable strains of $B$. thuringiensis with pronounced insecticidal action were selected for the study. Biological properties of strains are summarized in Table 1.

1. Biological characteristics of the compared Bacillus thuringiensis strains of different serogroups

\begin{tabular}{|c|c|c|c|c|c|}
\hline \multirow[b]{2}{*}{$\begin{array}{l}\text { № } \\
\text { strain }\end{array}$} & \multirow[b]{2}{*}{ Isolated object } & \multirow[b]{2}{*}{$\begin{array}{l}\text { Spore titer, } \\
\times 10^{9} / \mathrm{ml} \text { of } \\
\mathrm{LC}\end{array}$} & \multirow{2}{*}{$\begin{array}{l}\text { Exotoxin content } \\
\left(\mathrm{LC}_{50}, \mu \mathrm{l} / \mathrm{g} \text { of feed }\right. \\
\left.\text { for house fly } \mathrm{L}_{2}\right)\end{array}$} & \multicolumn{2}{|c|}{ Insecticidal activity $\mathrm{LC}_{50}, \%$} \\
\hline & & & & $\begin{array}{l}\text { to Colorado po- } \\
\text { tato beetle } \mathrm{L}_{2}\end{array}$ & $\begin{array}{l}\text { to yellow fever } \\
\text { mosquito } \mathrm{L}_{4} \\
\left(\times 10^{-3}\right)\end{array}$ \\
\hline \multicolumn{6}{|c|}{ B. thuringiensis var. thuringiensis } \\
\hline 12 & $\begin{array}{l}\text { Dead Colorado potato } \\
\text { beetle }\end{array}$ & 2.79 & 3.40 & 0.22 & - \\
\hline 20 & $\begin{array}{l}\text { Sick cabbage moth } \\
\text { caterpillar }\end{array}$ & 2.58 & 4.00 & 0.26 & - \\
\hline 40 & Caddage field soil & 2.42 & 4.29 & 0.32 & - \\
\hline $800 / 19$ & $\begin{array}{l}\text { Dead cabbage pierid } \\
\text { caterpillar }\end{array}$ & 2.72 & 3.78 & 0.28 & - \\
\hline \multicolumn{6}{|c|}{$\begin{array}{l}3.78 \\
\text { B. thuringiensis subsp. darmstadiensis }\end{array}$} \\
\hline 79 & $\begin{array}{l}\text { Dead Colorado potato } \\
\text { beetle }\end{array}$ & 1.98 & 5.86 & 0.42 & - \\
\hline 109 & $\begin{array}{l}\text { Colorado potato beetle } \\
\text { larvae }\end{array}$ & 2.78 & 4.28 & 0.36 & - \\
\hline $109 / 4$ & $\begin{array}{l}\text { Reisolation from Colo- } \\
\text { rado potato beetle larvae }\end{array}$ & 3.08 & 3.80 & 0.32 & - \\
\hline $109 / 57$ & $\begin{array}{l}\text { Reisolation from Colo- } \\
\text { rado potato beetle larvae }\end{array}$ & 3.25 & 3.60 & 0.27 & - \\
\hline \multicolumn{6}{|c|}{ B. thuringiensis var. israelensis } \\
\hline 38 & $\begin{array}{l}\text { Aedogenic water reser- } \\
\text { voir (water) }\end{array}$ & 2.81 & - & - & 0.24 \\
\hline 44 & $\begin{array}{l}\text { Anophelogenic water } \\
\text { reservoir (soil) }\end{array}$ & 3.28 & - & - & 0.16 \\
\hline
\end{tabular}

B. thuringiensis var. thuringiensis strains are active against Colorado potato beetle and lepidopteran pests, while $B$. thuringiensis subsp. darmstadiensis is effective primarily against coleopteran insect herbivores (Colorado potato beetle, flea beetles, rape blossom beetle, oriental mustard leaf beetle, raspberry and strawberry weevil, etc.). Representatives of $B$. thuringiensis var. israelensis have larvicidal activity and are effective against mosquitoes. Two strains of the analyzed ones (109/4 и 109/57) are variants of the B. thuringiensis subsp. darmstadiensis 109 strain chosen as a result of selection (see Table 1).

Upon obtaining the whole genome sequences of $B$. thuringiensis strains having different serotypes, their comparative analysis and the search for the most divergent genetic loci were performed. The genes that determine strain virulence and the genes required to sustain the essential life functions of microorganism cells (named housekeeping genes) were compared. As a result, 10 housekeeping genes ( $g l p T, g l p F, p y r E$, purF, purH, pta, gyrB, ftsA, panC and isd), as well as 8 virulence genes ( $h b l A, h b l C, h b l D$, nhe $A$, nhe $C$, capA, capC and inA) were selected (Table 2). 
2. Housekeeping and virulence genes studied in comparative analysis of whole genome sequences in 10 Bacillus thuringiensis strains having insecticidal activity

\begin{tabular}{|c|c|c|c|}
\hline Gene & $\begin{array}{l}\text { Fragment } \\
\text { size, bp }\end{array}$ & Coded protein & Reference \\
\hline \multicolumn{4}{|c|}{ Housekeeping genes } \\
\hline $\operatorname{glp} T$ & 1350 & glycerol-3-phosphate permease & {$[11]$} \\
\hline $\operatorname{glpF}$ & 837 & glycerol uptake facilitator protein & {$[12,14]$} \\
\hline pyrE & 633 & orotate phosphoribosyltransferase & {$[11]$} \\
\hline purF & 1416 & glutamine phosphoribosylpyrophosphate amidotransferase & [13] \\
\hline purH & 1536 & phosphoribosylaminoimidazole carboxamide formyltransferase & [14] \\
\hline pta & 972 & phosphate acetyltransferase & {$[12,14]$} \\
\hline $\operatorname{gyr} B$ & 1883 & DNA gyrase subunit B & {$[15]$} \\
\hline fts $A$ & 1308 & cell division protein & {$[11]$} \\
\hline panC & 849 & pantoate-beta-alanine ligase & {$[13]$} \\
\hline isd & 1025 & $\begin{array}{l}\text { iron-regulated surface determinant protein } \\
\qquad \mathrm{Virule} \mathrm{nce} \text { ge } \mathrm{nes}\end{array}$ & This article \\
\hline$h b l A$ & 1388 & hemolytic enterotoxin hemolysin A & {$[16,17]$} \\
\hline$h b l C$ & 1340 & hemolytic enterotoxin hemolysin C & {$[16,17]$} \\
\hline$h b l D$ & 1221 & hemolytic enterotoxin hemolysin D & {$[17]$} \\
\hline nhe $A$ & 1161 & nonhemolytic enterotoxin A & {$[16]$} \\
\hline nheC & 1080 & nonhemolytic enterotoxin $\mathrm{C}$ & {$[16]$} \\
\hline $\operatorname{cap} A$ & 748 & capsular polysaccharide A & {$[18]$} \\
\hline $\operatorname{cap} C$ & 768 & capsular polysaccharide $\mathrm{C}$ & {$[18]$} \\
\hline in $A$ & 2388 & metalloprotease & {$[18]$} \\
\hline
\end{tabular}

3. Number of different nucleotides in housekeeping gene referent complexes in 10 Bacillus thuringiensis strains having insecticidal activity at pairwise comparisons

\begin{tabular}{|c|c|c|c|c|c|c|c|c|c|c|}
\hline \multirow{2}{*}{ Strain } & \multicolumn{4}{|c|}{ var. thuringiensis } & \multicolumn{4}{|c|}{ subsp. darmstadiensis } & \multicolumn{2}{|c|}{ var. israelensis } \\
\hline & 40 & 12 & 20 & $800 / 19$ & 109 & $109 / 4$ & $109 / 57$ & 79 & 38 & 44 \\
\hline \multicolumn{11}{|l|}{$\overline{40}$} \\
\hline 12 & 12 & & & & & & & & & \\
\hline 20 & 27 & 15 & & & & & & & & \\
\hline $800 / 19$ & 18 & 6 & 21 & & & & & & & \\
\hline 109 & 352 & 345 & 360 & 350 & & & & & & \\
\hline $109 / 4$ & 357 & 351 & 366 & 343 & 7 & & & & & \\
\hline $109 / 57$ & 354 & 346 & 361 & 351 & 3 & 8 & & & & \\
\hline 79 & 346 & 339 & 354 & 344 & 20 & 25 & 21 & & & \\
\hline 38 & 414 & 399 & 424 & 414 & 188 & 195 & 191 & 190 & & \\
\hline 44 & 413 & 408 & 423 & 414 & 192 & 199 & 195 & 194 & 24 & \\
\hline
\end{tabular}

4. Number of different nucleotides in virulence gene referent complexes in $10 \mathrm{Ba}$ cillus thuringiensis strains having insecticidal activity at pairwise comparisons

\begin{tabular}{|c|c|c|c|c|c|c|c|c|c|c|}
\hline \multirow{2}{*}{ Strain } & \multicolumn{4}{|c|}{ var. thuringiensis } & \multicolumn{4}{|c|}{ subsp. darmstadiensis } & \multicolumn{2}{|c|}{ var. israelensis } \\
\hline & 40 & 12 & 20 & $800 / 19$ & 109 & $109 / 4$ & $109 / 57$ & 79 & 38 & 44 \\
\hline 40 & & & & & & & & & & \\
\hline 12 & 18 & & & & & & & & & \\
\hline 20 & 8 & 12 & & & & & & & & \\
\hline $800 / 19$ & 15 & 3 & 9 & & & & & & & \\
\hline 109 & 296 & 300 & 292 & 299 & & & & & & \\
\hline $109 / 4$ & 296 & 300 & 292 & 299 & 0 & & & & & \\
\hline $109 / 57$ & 296 & 300 & 292 & 299 & 0 & 0 & & & & \\
\hline 79 & 276 & 279 & 270 & 277 & 229 & 229 & 229 & & & \\
\hline 38 & 385 & 389 & 379 & 386 & 420 & 420 & 420 & 394 & & \\
\hline 44 & 383 & 399 & 389 & 396 & 429 & 429 & 429 & 403 & 29 & \\
\hline
\end{tabular}

These loci, except for the isd gene, have been previously used by other authors for genotyping and studying of biodiversity of $B$. cereus and $B$. thuringiensis strains [11-18]. In this study, a high level of genetic divergence in the isd locus was identified. For each strain, two referent complexes were constructed, representing the sequences of selected housekeeping loci and virulence genes taken separately. Total length of referent complexes was 11,809 and 10,094 bp, respectively. The data on the number of different nucleotides in referent complexes in the studied strains of $B$. thuringiensis at pairwise compari- 
sons are summarized in Tables 3 and 4. One can see that the most homologous housekeeping genes were typical for $B$. thuringiensis subsp. darmstadiensis strains $109,109 / 4$ and 109/57 (3-8 different nucleotides) and B. thuringiensis var. thuringiensis strains 12, 20 and 800/19 having from 6 to 21 different nucleotides (see Table 3). Strains 109, 109/4 and 109/57 that are the variants of the same strain, were identical while the 12, 20 and 800/19 closely related strains had from 3 to 12 different nucleotides (see Table 4).

Phylogenetic relationship of $B$. thuringiensis strains studied was shown more evident by dendrograms obtained based on the referent complex analysis of housekeeping and virulence genes (Fig. 1 and 2). One can see that in both cases, strains are grouped strictly according to their taxonomic position and serotype which indicates high taxonomic significance of the loci used.

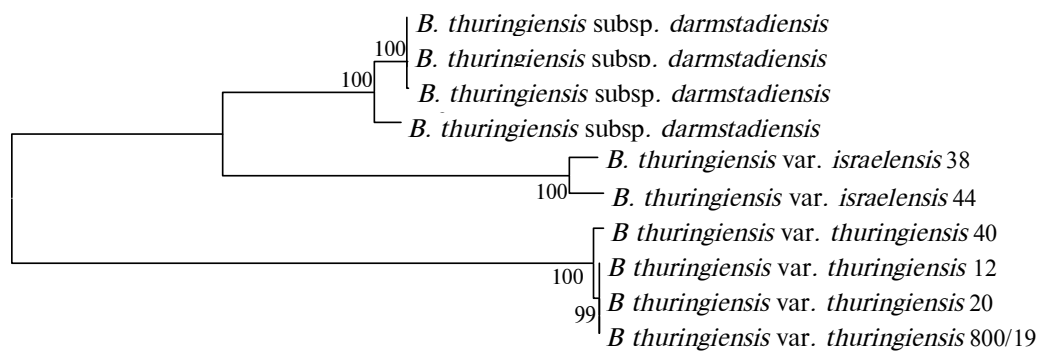

Fig. 1. Dendrogram for Bacillus thuringiensis strains with insecticidal activity based on the referent complex analysis including housekeeping genes glp $T, g l p F, p y r E, p u r F, p u r H, p t a, g y r B$, fts $A$, panC and isd.

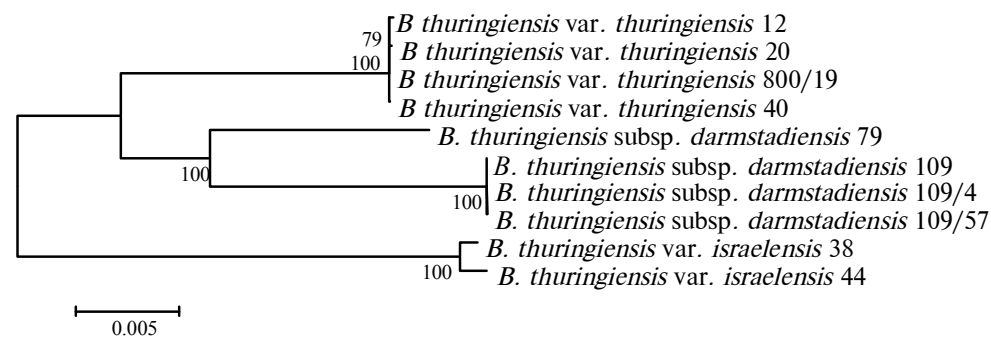

Fig. 2. Dendrogram for Bacillus thuringiensis strains with insecticidal activity based on the referent complex analysis including virulence genes $h b l A, h b l C, h b l D$, nhe $A, n h e C, \operatorname{cap} A, \operatorname{cap} C$ and in $A$.

Thus, unique housekeeping and virulenceas genes have been identified as a result of a comparative whole genome sequence analysis of 10 Bacillus thuringiensis strains having different serotype, sequencing of which will allow the rapid authentication of commercial strains of the species for monitoring quality of microbial material in the manufacture of biologics with insecticidal effect.

\section{R E F E R E N C ES}

1. Paun O., Schönswetter P. Amplified fragment length polymorphism: an invaluable fingerprinting technique for genomic, transcriptomic, and epigenetic studies. Methods Mol. Biol., 2012, 862: 75-87 (doi: 10.1007/978-1-61779-609-8_7).

2. Leblond P., Decaris B. Shromosome geometry and intraspecific genetic polymorphism in Grampositive bacteria revealed by pulsed-field gel electrophoresis. Electrophoresis, 1998, 19(4): 582-588.

3. N a s o n o v a E.S. Tsitologiya, 2008, 50(11): 927-935.

4. Bull-Otterson L., Feng W., Kirpich I., Wang Y., Qin X., Liu Y., Gobejishvili L., Joshi-Barve S., Ayvaz T., Petrosino J., Kong M., Barker D., M c Clain C., B arve S. Metagenomic analyses of alcohol induced pathogenic alterations in the intestinal microbiome and the effect of Lactobacillus rhamnosus GG treatment. PLoS ONE, 2013, 8(1): e53028 (doi: 10.1371/journal.pone.0053028). 
5. Džunková M., D’Auria G., Pérez-Villarroya D., Moya A. Hybrid sequencing approach applied to human fecal metagenomic clone libraries revealed clones with potential biotechnological applications. PLOS ONE, 2012, 7(10): e47654 (doi: 10.1371/journal.pone.0047654).

6. White J., Gilbert J., Hill G., Hill E., Huse S.M., Weightman A.J., Mahenthiralingam E. Culture-independent analysis of bacterial fuel contamination provides insight into the level of concordance with the standard industry practice of aerobic cultivation. Appl. Environ. Microbiol., 2011, 77(13): 4527-4538 (doi: 10.1128/AEM.02317-10).

7. Nacke H., Thürmer A., Wollherr A., Will C., Hodac L., Herold N., Schöning I., Schrumpf M., Daniel R. Pyrosequencing-based assessment of bacterial community structure along different management types in German forest and grassland soils. PLoS ONE, 2011, 6(2): e17000 (doi: 10.1371/journal.pone.0017000).

8. Petrosino J.F., Highlander S., Luna R.A., Gibbs R.A., Versalovic J. Metagenomic pyrosequencing and microbial identification. Clin. Chem., 2009, 55(5): 856-866 (doi: 10.1373/clinchem.2008.107565).

9. S afronova V.I., Osledkin Yu.S., Sviridova O.V., Vorob'ev N.I. Metody konservatsii kollektsionnykh kul'tur mikroorganizmov [Preservation of microorganisms in collections]. St. Petersburg, 2007.

10. Safronova V., Tikhonovi ch I. Automated cryobank of microorganisms: Unique possibilities for long-term authorized depositing of commercial microbial strains. In: Microbes in applied research: current advances and challenges. A. Mendez-Vilas (ed.). World Scientific Publishing Co., 2012: 331-334 (doi:10.1142/9789814405041_0066).

11. Helgason E., Tourasse N.J., Me is a 1 R., Caugant D.A., Kols to A.B. Multilocus sequence typing scheme for bacteria of the Bacillus cereus group. Appl. Environ. Microbiol., 2004, 70: 191-201 (doi: 10.1128/AEM.70.1.191-201.2004).

12. Barker M., Thakker B., Priest F.G. Multilocus sequence typing reveals that Bacillus cereus strains isolated from clinical infections have distinct phylogenetic origins. FEMS Microbiol. Lett., 2005, 245: 179-184.

13. Sorokin A., Candelon B., Guilloux K., Galleron N., WackerowKouzova N., Ehrlich S.D., Bourguet D., S a nchis V. Multiple-locus sequence typing analysis of Bacillus cereus and Bacillus thuringiensis reveals separate clustering and a distinct population structure of psychrotrophic strains. Appl. Environ. Microbiol., 2006, 72: 1569-1578 (doi: 10.1128/AEM.72.2.1569-1578.2006).

14. S oufi a ne B., B a iz et M., Côt é J.C. Multilocus sequence analysis of Bacillus thuringiensis serovars navarrensis, bolivia and vazensis and Bacillus weihenstephanensis reveals a common phylogeny. Antonie Van Leeuwenhoek, 2013, 103(1): 195-205 (doi: 10.1007/s10482-012-9800-5).

15. Ko K.S., Kim J.W., Ki m J.M., Kim W., Chung S.I., Kim I.J., Kook Y.H. Population structure of the Bacillus cereus group as determined by sequence analysis of six housekeeping genes and the plcR gene. Infect. Immun., 2004, 72: 5253-5261 (doi: 10.1128/IAI.72.9.5253-5261.2004).

16. Rahimi E., Abdos F., Momtaz H., Baghbadorani Z.T., Jalali M. Bacillus cereus in infant foods: prevalence study and distribution of enterotoxigenic virulence factors in Isfahan Province, Iran. Scientific World Journal, 2013, 2013: 292571 (doi: 10.1155/2013/292571).

17. K i m Y.R., B at t C.A. Riboprint and virulence gene patterns for Bacillus cereus and related species. J. Microbiol. Biotechnol., 2008, 18(6): 1146-1155.

18. Zahner V., Silva A.C., De Moraes G.P., Me Intosh D., De Filippis I. Extended genetic analysis of Brazilian isolates of Bacillus cereus and Bacillus thuringiensis. Mem. Inst. Oswaldo Cruz (Rio de Janeiro), 2013, 108(1): 65-72. 